NATIONAL LABORATORY

\title{
Mixing Appropriations and Private Financing to Meet Federal Energy Management Goals
}

\section{June 2012}

Prepared by

John Shonder

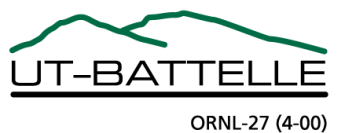




\section{DOCUMENT AVAILABILITY}

Reports produced after January 1, 1996, are generally available free via the U.S. Department of Energy (DOE) Information Bridge.

Web site http://www.osti.gov/bridge

Reports produced before January 1, 1996, may be purchased by members of the public from the following source.

National Technical Information Service

5285 Port Royal Road

Springfield, VA 22161

Telephone 703-605-6000 (1-800-553-6847)

TDD 703-487-4639

Fax 703-605-6900

E-mail info@ntis.gov

Web site http://www.ntis.gov/support/ordernowabout.htm

Reports are available to DOE employees, DOE contractors, Energy Technology Data Exchange (ETDE) representatives, and International Nuclear Information System (INIS) representatives from the following source.

Office of Scientific and Technical Information

P.O. Box 62

Oak Ridge, TN 37831

Telephone 865-576-8401

Fax 865-576-5728

E-mail reports@osti.gov

Web site http://www.osti.gov/contact.html

This report was prepared as an account of work sponsored by an agency of the United States Government. Neither the United States Government nor any agency thereof, nor any of their employees, makes any warranty, express or implied, or assumes any legal liability or responsibility for the accuracy, completeness, or usefulness of any information, apparatus, product, or process disclosed, or represents that its use would not infringe privately owned rights. Reference herein to any specific commercial product, process, or service by trade name, trademark, manufacturer, or otherwise, does not necessarily constitute or imply its endorsement, recommendation, or favoring by the United States Government or any agency thereof. The views and opinions of authors expressed herein do not necessarily state or reflect those of the United States Government or any agency thereof. 
Building Technologies, Research, and Integration Center

\title{
Mixing Appropriations and Private Financing To Meet Federal Energy Management Goals
}

\author{
John Shonder
}

Date Published: June 2012

Prepared by

OAK RIDGE NATIONAL LABORATORY

Oak Ridge, Tennessee 37831-6283

managed by

UT-BATTELLE, LLC

for the

U.S. DEPARTMENT OF ENERGY

under contract DE-AC05-00OR22725 


\section{CONTENTS}

Page

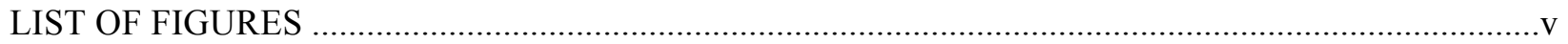

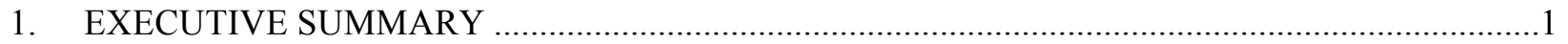

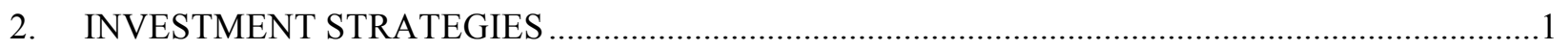

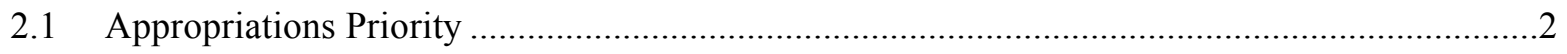

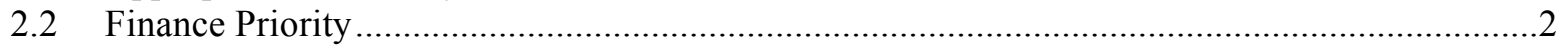

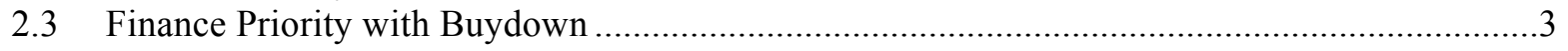

3. BASIS FOR THE ENERGY EFFICIENCY MEASURES REPRESENTED IN THE

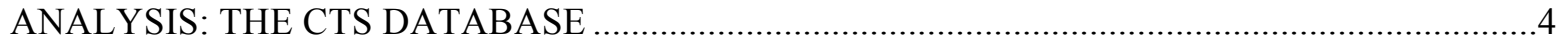

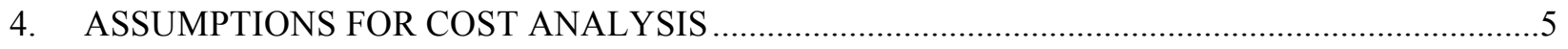

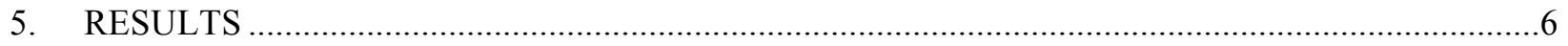

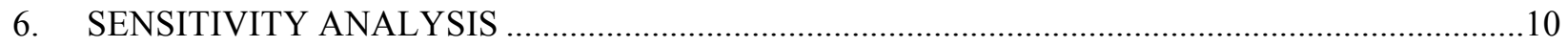

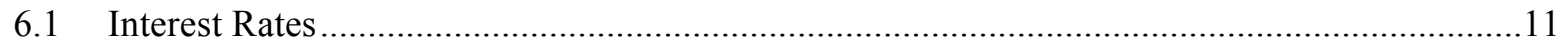

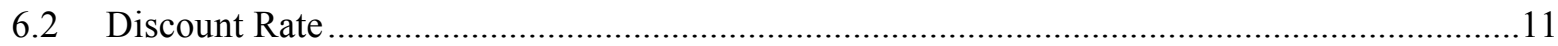

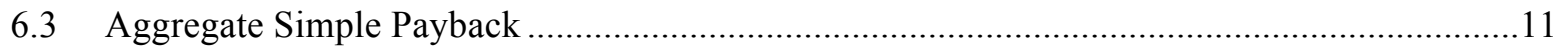

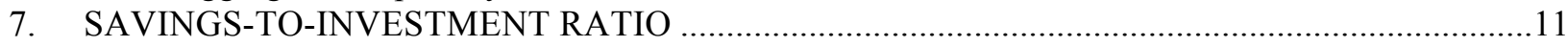

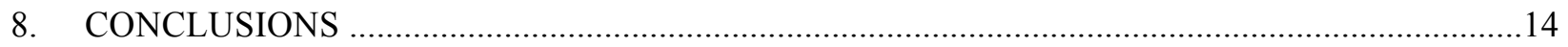

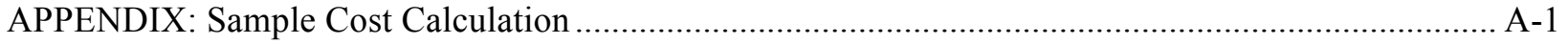





\section{LIST OF FIGURES}

Figure

Page

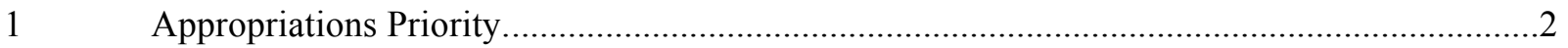

2

Finance Priority.

Finance Priority with Buydown.

Percentage of total savings vs. percentage of total investment, for measures grouped in order of simple payback from shortest to longest, from FEMP's EISA 432 Compliance Tracking System database.

Maximum possible investment for the Appropriations Priority strategy, in which appropriations are used to directly fund efficiency measures with the shortest paybacks, for the mix of ECMs defined in the report. Life-cycle cost of the three strategies for implementing the total amount of investment shown in Fig. 1 for each level of available appropriations. .8

7 Maximum investment for the Finance Priority and Finance Priority with Buydown strategies, by amount of available appropriations.

Life-cycle cost of strategies 2 and 3, by amount of available appropriations. of total savings vs. percentage of total investment for a truncated dataset with an aggregate simple payback of 13 years and a maximum simple payback of 20 Maximum possible investment for the Appropriations Priority strategy, for the truncated ECM distribution of Fig. 9.

11 Life-cycle cost of the three strategies for implementing the total amount of investment shown in Fig. 10 for each level of available appropriations, for the truncated ECM distribution shown in Fig. 9. 



\section{EXECUTIVE SUMMARY}

This report compares several strategies for mixing appropriations and private financing in a typical federal agency that has identified $\$ 100$ million in required energy conservation measures (ECMs) at its facilities. In addition to available appropriations, the agency is assumed to have access to private financing at interest rates that match the rates being obtained in Energy Savings Performance Contracts (ESPCs) awarded under the US Department of Energy's (DOE) ESPC program as of April 2012.

The analysis shows that in order to maximize savings and minimize overall life-cycle cost, the best strategy for the agency is to use private financing to fund as many of the ECMs as possible within the statutory maximum 25-year project term, beginning with the ECMs with the shortest paybacks. Available appropriations should either be applied to a privately financed project as a one-time payment from savings (i.e., as a "buydown") or used to directly fund longer-payback ECMs that cannot be included in the privately financed project.

The analysis shows that using appropriations to directly fund the ECMs with the shortest paybacks has several disadvantages. First, it limits the amount of investment in energy conservation that can be made by the agency, thereby limiting the amount of energy savings that can be obtained. This is because removing short-payback ECMs from a privately financed project reduces the size of the project by much more than the amount of investment removed. In fact, the results show that every dollar used to directly fund short-payback ECMs reduces the size of the privately financed project by $\$ 3.83$ - thereby reducing total investment by $\$ 2.83$. As more and more appropriations are used to directly fund short-payback measures, a point is reached at which privately financed projects become impossible: the savings per dollar investment for even the best of the remaining measures is too small to pay off their debt service within the statutory maximum contract term of 25 years. In the representative case analyzed, this occurs when appropriations are about $\$ 30$ million. At this point, the agency is completely dependent on further Congressional appropriations to fund energy efficiency projects at its sites.

Finally, the analysis shows that using appropriations to directly fund the shortest-payback efficiency measures is also more costly for an agency. The reason is that, again, removing short-payback measures from a privately financed project makes the remaining measures more costly to implement.

\section{INVESTMENT STRATEGIES}

Agencies of the US government are required by legislation and executive order to meet a number of goals related to energy management. For example, the Energy Independence and Security Act of 2007 requires agencies to reduce their energy use by 30\% compared with an FY 2003 baseline. The Energy Policy Act of 2005 requires that the federal government's renewable electricity consumption equal or exceed $3 \%$ of total electricity consumption from FYs 2007 to 2009, with increases to at least 5\% in FYs 2010-2012 and $7.5 \%$ in 2013 and thereafter. Other goals exist for reductions in water use, greenhouse gas emissions, and the use of fossil fuels in new construction and major renovations of existing facilities.

Agencies have two main sources for the funds needed to meet these goals: funding appropriated by Congress, and private financing, which is typically accessed through Energy Savings Performance Contracts (ESPCs) and Utility Energy Services Contracts (UESCs). Given the requirements of their facilities, agencies must decide how to make best use of the limited appropriations they receive from Congress and the private financing made available through utilities and energy service companies. This report considers three different strategies, which are described below. 


\subsection{APPROPRIATIONS PRIORITY}

The Appropriations Priority strategy is illustrated in Fig. 1. The agency is assumed to have a list of available energy efficiency measures ranked in order from shortest to longest simple payback. Given the level of appropriations available, the agency directly funds as many of the shortest-payback efficiency measures as possible. As many of the remaining efficiency measures as possible within the statutory maximum 25-year project term are then implemented in a privately financed project.

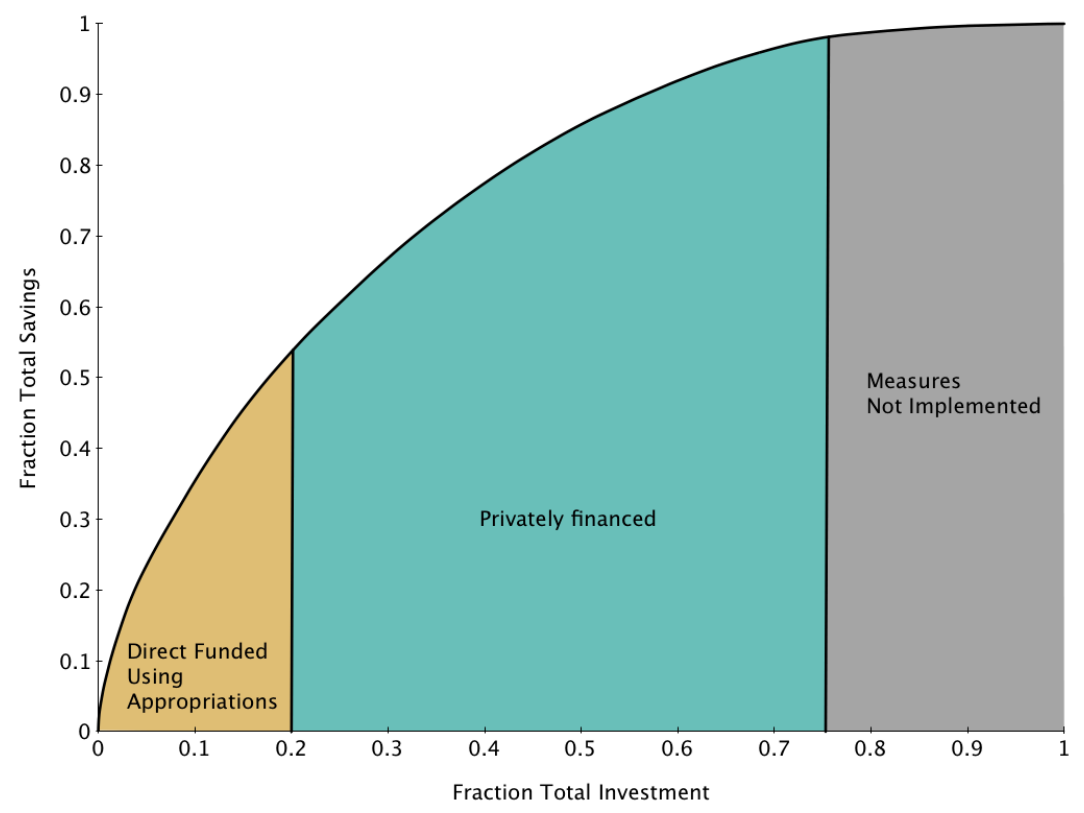

Fig. 1. Appropriations Priority. Appropriations are used to implement the shortest-payback measures in directly funded projects. As much of the remainder as possible is funded using private financing.

Depending on economic factors, it may not be possible to implement all of the remaining measures using private financing, especially when the measures with the shortest paybacks are no longer available to be bundled. Figure 1 illustrates a situation in which about $24 \%$ of the total investment cannot be implemented at all.

\subsection{FINANCE PRIORITY}

The Finance Priority strategy is illustrated in Fig. 2. Beginning with the shortest-payback measures, the agency uses private financing to implement as many of the efficiency measures as possible within the statutory maximum 25-year project term. Available appropriations are then used to fund as many of the remaining measures as possible. Again, depending on the distribution of ECMs and economic factors such as interest rates, it may not be possible to implement all of the remaining ECMs using an ESPC. Figure 2 shows a situation in which about $75 \%$ of the required investment can be implemented using private financing within the statutory maximum 25-year project term. Appropriations are used to fund an additional $10 \%$ of the required investment. 


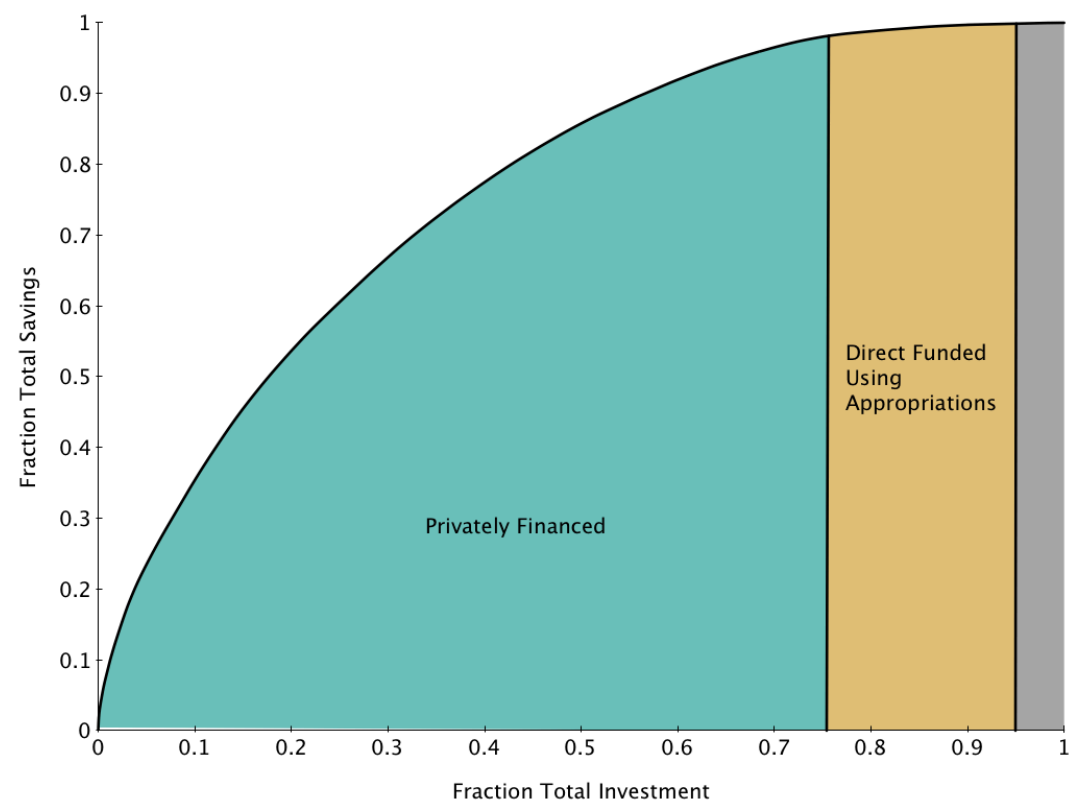

Fig. 2. Finance Priority. As many efficiency measures as possible are implemented with private financing, beginning with the measures with the shortest paybacks. Appropriations are used to directly fund as many of the remaining measures as possible.

\subsection{FINANCE PRIORITY WITH BUYDOWN}

Figure 3 illustrates the Finance Priority with Buydown strategy. In this case, the agency uses private financing to implement as many of the measures as possible, applying the available appropriations as an up-front payment or "buydown" in the privately financed project. As in the other scenarios, the mix of efficiency measures and economic factors may be such that even with the up-front payment, not all measures can be implemented in a privately financed project with a term of less than 25 years. Figure 3 presents a situation in which about $91 \%$ of total investment can be implemented in a privately financed project with a term under the statutory maximum of 25 years, given an up-front payment of $20 \%$ of total investment. 


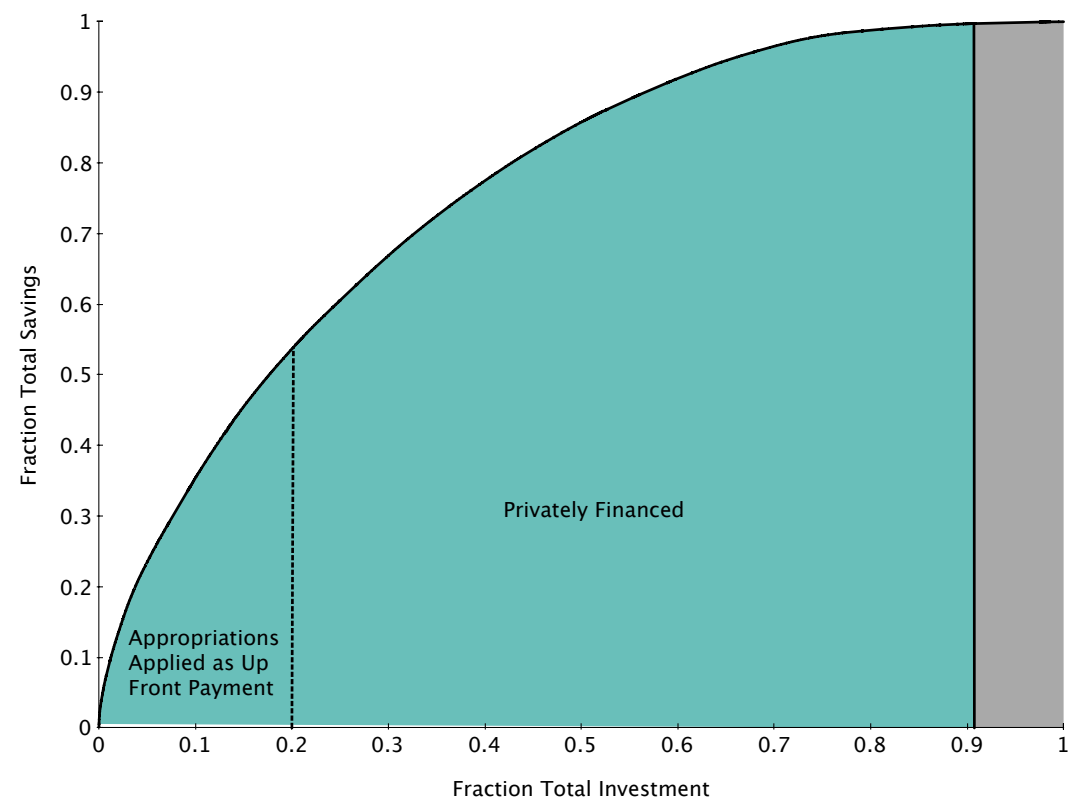

Fig. 3. Finance Priority with Buydown. Private financing is used to implement as many efficiency measures as possible, beginning with the measures with the shortest paybacks. Appropriations are applied as a buydown in the financed project.

\section{BASIS FOR THE ENERGY EFFICIENCY MEASURES REPRESENTED IN THE ANALYSIS: THE CTS DATABASE}

Quantitative comparison of the various options requires the assumption of a set of efficiency measures representative of measures seen broadly across the entire federal government. Fortunately, a representative database of such measures exists. Section 432 of the Energy Independence and Security Act of 2007 (EISA) required federal agencies to identify all "covered facilities" that constitute at least $75 \%$ of the agency's facility energy use. Facility managers were then responsible for completing comprehensive energy and water evaluations of $25 \%$ of covered facilities each year, so that an evaluation of each facility is completed at least once every 4 years. The results of the audits-including the estimated implementation cost and cost savings - are entered into the "EISA Section 432 Compliance Tracking System" (CTS). Maintained by DOE's Federal Energy Management Program (FEMP), the CTS database presently contains information on energy efficiency projects in more than 5,000 covered facilities in 72 different agencies and sub-agencies.

Analysis of the database began with calculation of the simple payback of each identified efficiency measure. The measures were sorted in order from shortest to longest simple payback. Running totals of cumulative investment and cumulative annual savings were calculated, and the running totals were divided by total investment and total savings, respectively, to convert them to percentage of total investment and percentage of total annual savings.

Figure 4 is a plot of the percentage of total annual savings vs. percentage of total investment for the entire CTS database. It shows, for example, that the $10 \%$ of investment corresponding to the efficiency measures with the shortest paybacks delivers $35 \%$ of the cost savings. Likewise, the $30 \%$ of investment corresponding to the shortest-payback measures delivers $66 \%$ of the cost savings. 


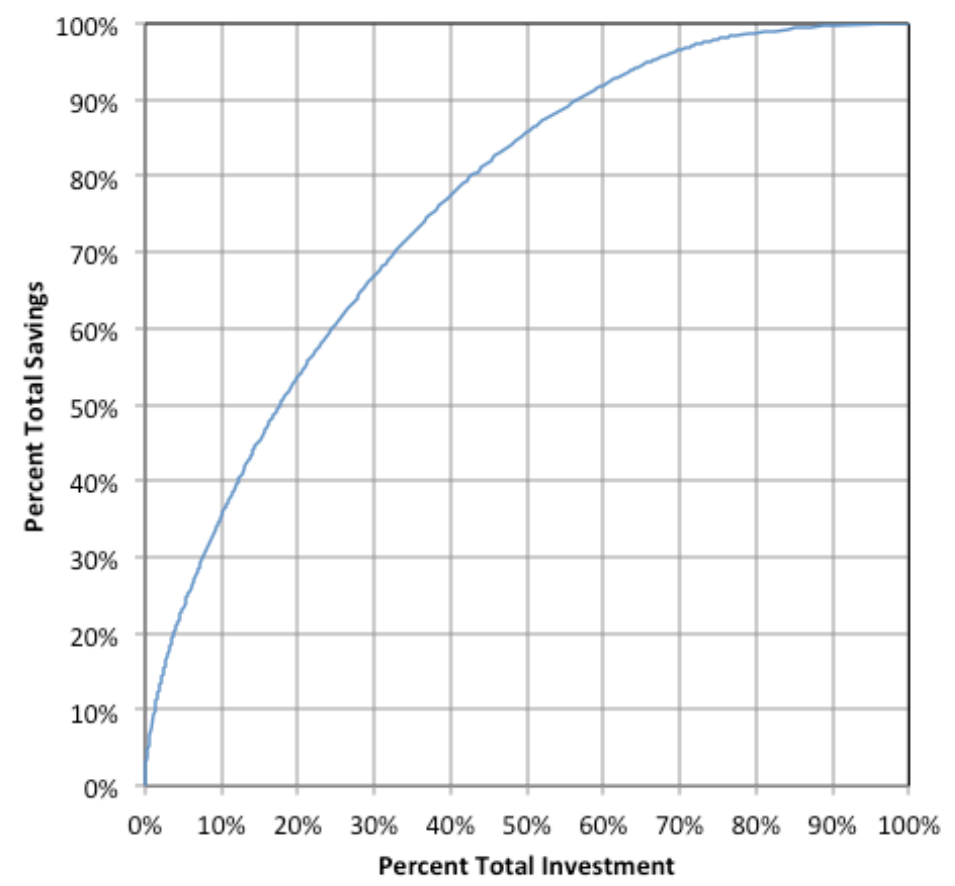

Fig. 4. Percentage of total savings vs. percentage of total investment, for measures grouped in order of simple payback from shortest to longest, from FEMP's EISA 432 Compliance Tracking System database.

Altogether, the projects in the CTS database represent an estimated total implementation cost of $\$ 8.9$ billion, with estimated annual cost savings of $\$ 818$ million. Note that, given current ESPC project interest rates (now averaging about $4 \%$ annually) and other reasonable assumptions for financial parameters, the aggregate simple payback of 10.97 means that the entire database of projects could be funded in a single, large, privately financed project with a term of 18 years.

The database presents a much different picture for individual agencies and sub-agencies, however. Aggregate simple payback for individual sub-agencies exceeds 25 years in some cases, meaning that not all of the investment could be captured in a single privately financed project with a term under the statutory maximum of 25 years. Based on the experience of many in the industry, this is the more common situation: it is usually not possible to finance all of the efficiency measures identified at a given site in one project with a term of 25 years or less.

Note, however, that the curve of Fig. 4 does not presume an aggregate simple payback. Therefore, to compare the economics of various strategies for funding an agency's required energy efficiency projects, the analysis used the curve of Fig. 4, but with an assumed aggregate simple payback of 17 years. This is half way between the mean and the median of the aggregate simple paybacks of the 72 reporting subagencies and seemed a reasonable value to use given the wide variation in aggregate simple payback among the individual sub-agencies.

\section{ASSUMPTIONS FOR COST ANALYSIS}

For this analysis, the agency is assumed to have identified $\$ 100$ million in necessary ECMs with an aggregate simple payback of 17 years. The curve of savings vs. investment for these ECMs is as in Fig. 4, where the ECMs are arranged from shortest to longest simple payback. Cost calculations are based on the following assumptions: 
1. Interest rate 108 basis points above a Treasury security with a like term on $4 / 5 / 2012$ for privately financed capital. This is the current average premium over like-term Treasury securities for the private financing received on projects awarded under DOE's ESPC program.

2. Inflation rate of $2 \%$. All costs and the guaranteed savings in the privately financed project increase annually at this rate.

3. Discount rate of $3.5 \%$ for life-cycle cost calculations. This is the nominal discount rate recommended for 20 year analyses in OMB Circular A-94 Appendix C (December 2011), available at http://www.whitehouse.gov/omb/circulars_a094/a94_appx-c.

4. Survey/study costs of 5\% are incurred in both directly funded and privately financed projects.

5. First-year operations and maintenance costs $(\mathrm{O} \& \mathrm{M})$ are assumed to be $1.2 \%$ of the implementation price for directly funded projects and $1.5 \%$ of the implementation price for privately financed projects. The higher cost in privately financed projects accounts for measurement and verification $(\mathrm{M} \& \mathrm{~V})$ of savings. Both costs increase annually at the inflation rate.

6. In the financed project, the payment to the energy services company (ESCO) is (up to) one dollar less than the guaranteed savings.

7. In the privately financed project, an annual payment is made to the ESCO at the beginning of the contract year for all of the savings that will occur during that year.

8. In the financed project, the ESCO incurs a financing procurement price equal to 2 years of interest on the financed amount. The financed amount is then equal to the base cost of the project, plus the 5\% survey/study cost, plus the financing procurement price.

9. A 2 year construction period is assumed, making the maximum performance period for the privately financed project equal to 23 years.

10. The study period is 25 years. No salvage costs are assumed.

A representative calculation is presented in the Appendix.

\section{RESULTS}

The analysis shows that for the distribution of ECMs analyzed, the practice of using appropriations to directly fund efficiency measures with the shortest paybacks - the Appropriations Priority strategy as designated above - has several disadvantages. First, it limits the amount of energy savings that can be achieved, making it more difficult to meet the energy management goals mandated by Congress and the President. To understand why, it helps to think of efficiency measures in financial terms, as sources of cost savings. Measures with short paybacks deliver larger savings per dollar invested, and measures with long paybacks deliver smaller savings per dollar invested. In financed projects, these streams of cost savings are used to pay the debt service on the borrowed capital (in addition to their use to fund M\&V and other performance period services). If an agency uses appropriations to directly fund short-payback measures, then the remaining measures generate less savings per dollar invested. The financed project is already at the statutory maximum contract term, so given a smaller savings stream, the only way to implement a financed project is to decrease the size of the loan. But reducing the size of the loan further reduces the size of the savings stream. This causes a multiplier effect: starting from zero, each additional appropriated dollar that is used to fund short-payback measures reduces the maximum possible size of the 
privately financed project by $\$ 3.83$. This means that each additional dollar of appropriations used to fund short-payback measures reduces total possible investment in energy efficiency by $\$ 2.83$. This is especially problematic given the recent memo from the President directing federal agencies to implement $\$ 2$ billion in privately financed energy-efficiency projects.

The results, presented graphically in Fig. 5, show that as more and more appropriations are used to directly fund short-payback measures, a point is reached at which privately financed projects become impossible: the savings per dollar investment for even the best of the remaining measures are too small to pay off their debt service within the statutory maximum contract term of 25 years. In the representative case analyzed, this occurs when appropriations are about $\$ 30$ million. At this point, the agency is completely dependent on further Congressional appropriations to fund energy efficiency projects at its sites.

In addition to limiting investment, using appropriations to directly fund the shortest-payback efficiency measures is more costly for an agency. Figure 6 presents the life-cycle cost of using the three strategies described earlier to implement the quantity of investment possible using the Appropriations Priority strategy. It is seen that of the three strategies, the Appropriations Priority strategy has the highest lifecycle cost to the agency. The reason is that, again, taking out the short-payback measures makes the remaining measures more costly to implement using private financing. In this case, it is possible to increase the project term, but doing so increases interest costs and raises the life-cycle cost.

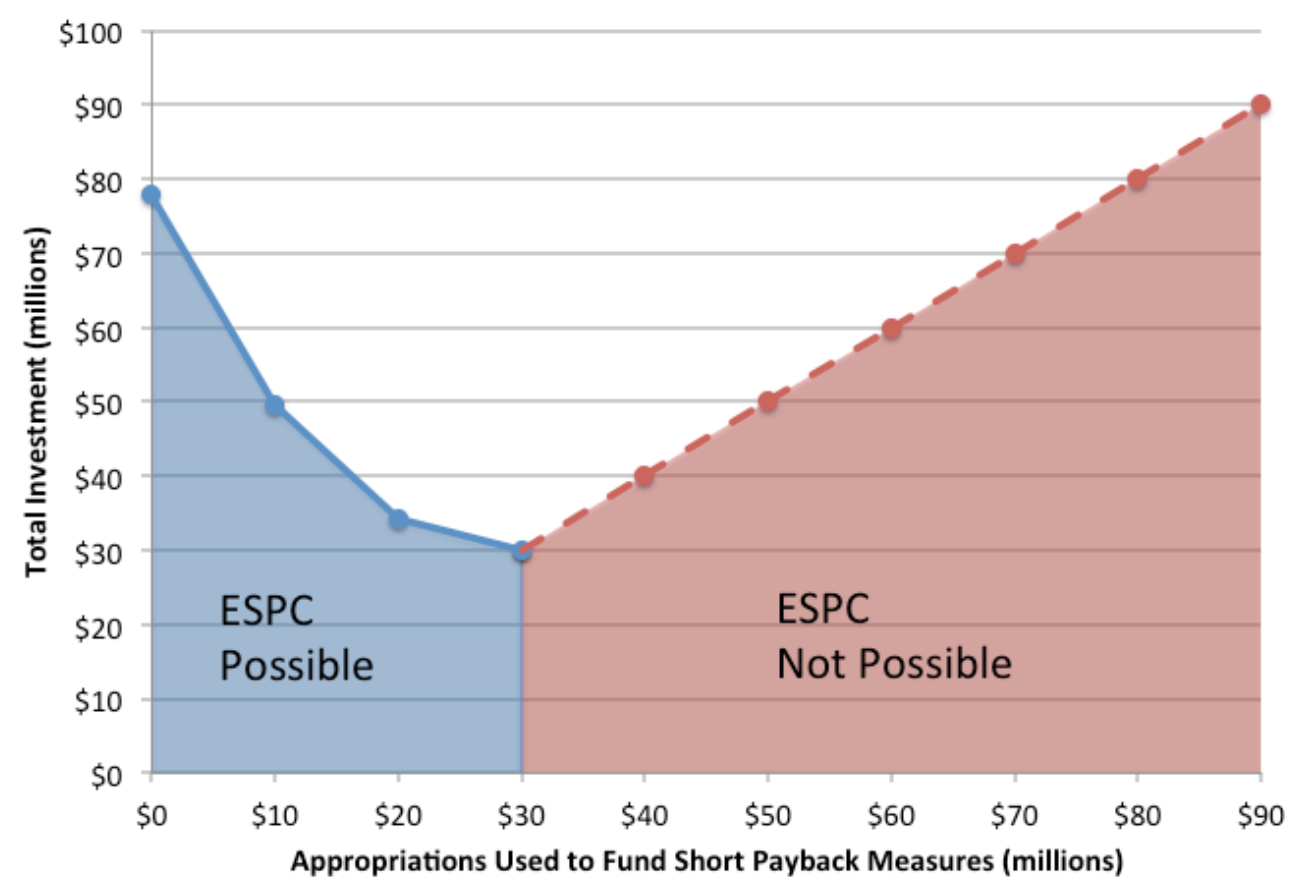

Fig. 5. Maximum possible investment for the Appropriations Priority strategy, in which appropriations are used to directly fund efficiency measures with the shortest paybacks, for the mix of ECMs defined in the report. The dotted line indicates the situation in which it is no longer possible to use private financing, because the savings will not pay off the investment within a 25 -year term. 


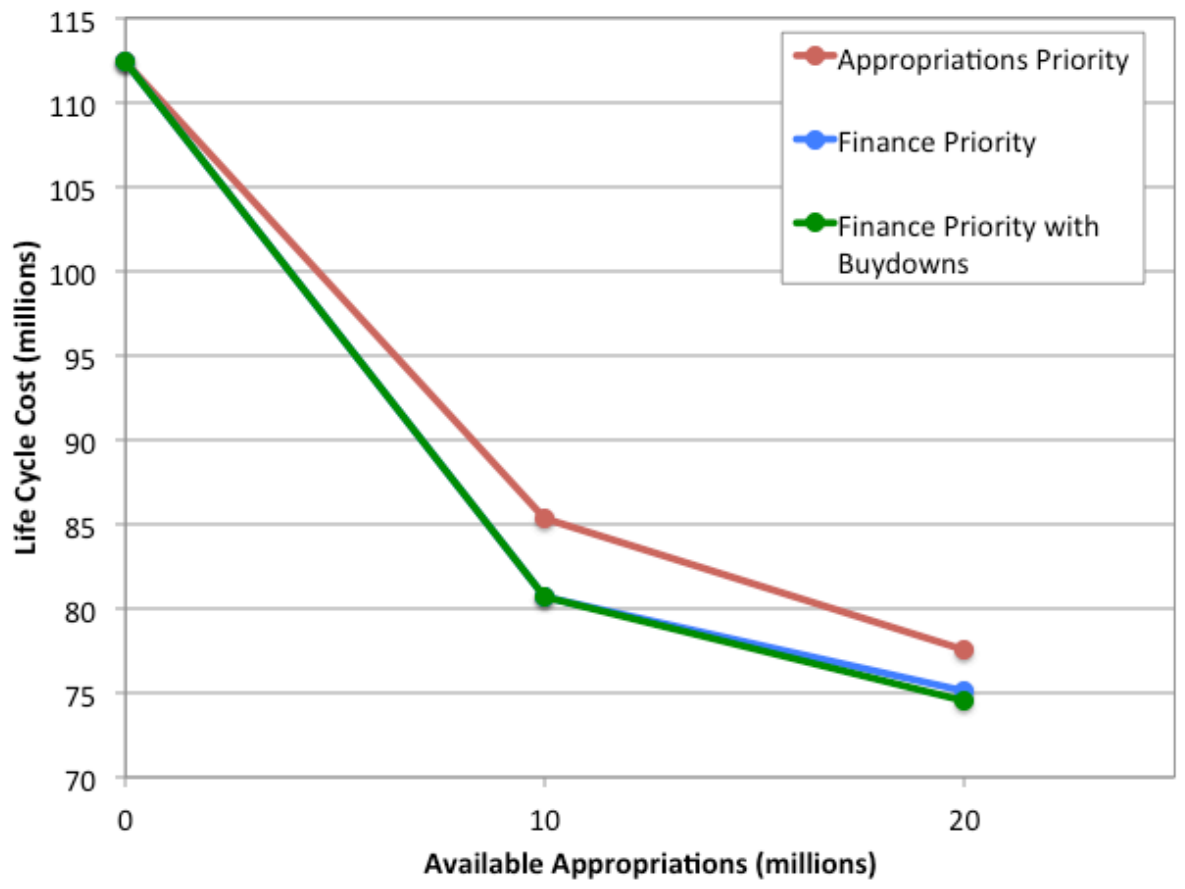

Fig. 6. Life-cycle cost of the three strategies for implementing the total amount of investment shown in Fig. 1 for each level of available appropriations.

The analysis shows that in order to maximize energy savings, the optimal strategy is for agencies to fund as many of their required energy efficiency measures as possible using private financing, beginning with the shortest-payback measures and continuing to add longer-payback measures until the project term is just under the statutory maximum of 25 years. Then if appropriations are available, the agency can either directly fund as many of the remaining efficiency measures as possible (beginning with the measures remaining that have the shortest simple paybacks), or apply the appropriations as an up-front payment in the financed project.

Figure 7 shows that when small amounts of appropriations are available, the Financing Priority strategy results in the largest possible investment. To see why, consider what happens when $\$ 10$ million in appropriations is available. Figure 7 shows that with $\$ 10$ million in appropriations, the agency can fund a total of \$87.9 million in investments: \$77.9 million using private financing and \$10 million in directly funded projects using the appropriations. Under the Financing with Buydowns strategy, however, in which the $\$ 10$ million is applied as an up-front payment, the ESCO cannot simply increase the amount of private investment by $\$ 10$ million dollars. Doing so increases financing costs, because the loan must be carried during the construction period, and the agency makes no payments until construction is complete. In order to pay interest to the financier during the construction period, the ESCO must overborrow by the amount of the capitalized interest that is due. As a result, the $\$ 10$ million up-front payment received at the end of the construction period buys less than $\$ 10$ million in additional project investment. In the case of Fig. 7, the $\$ 10$ million up-front payment permits an additional $\$ 7.7$ million in project investment. 


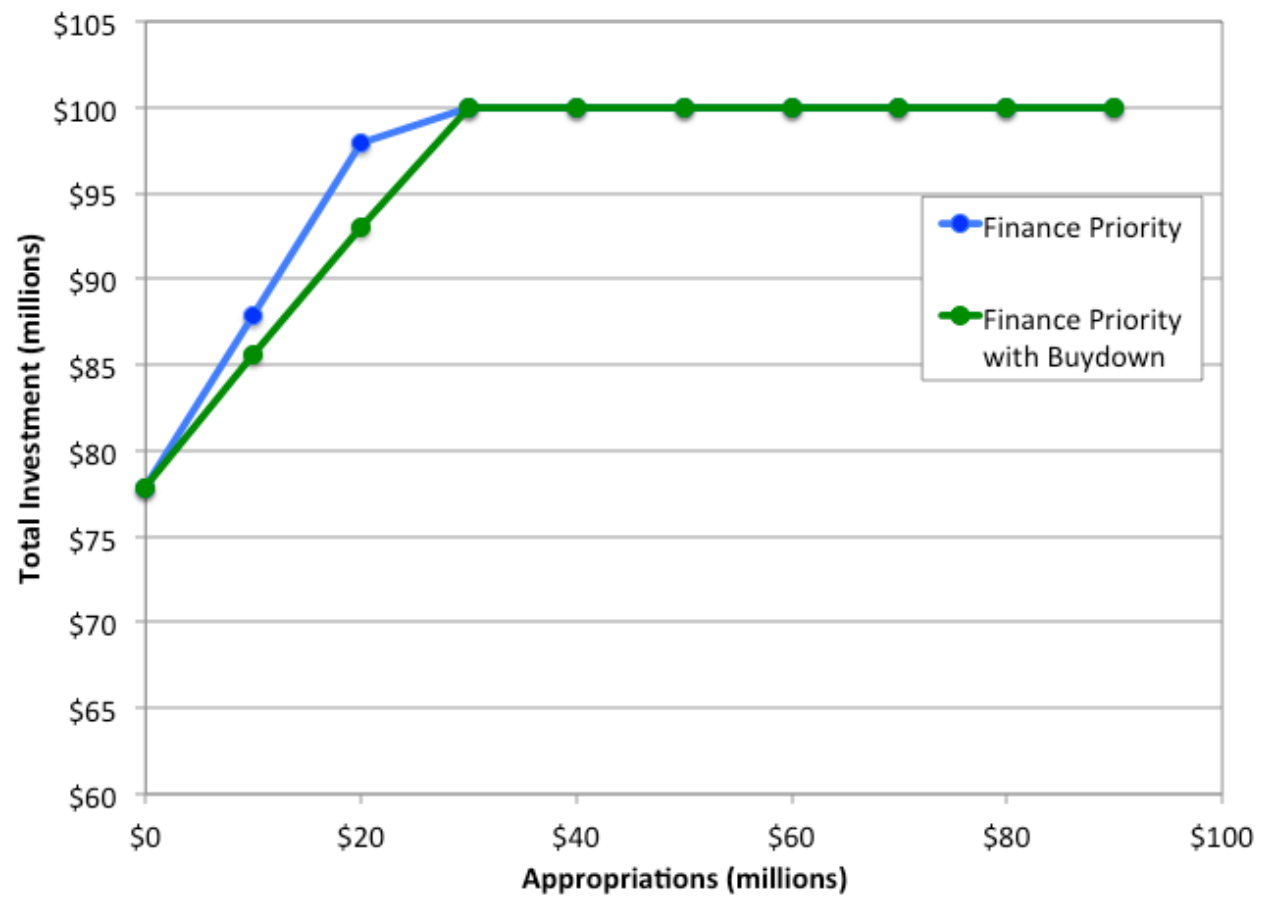

Fig. 7. Maximum investment for the Finance Priority and Finance Priority with Buydown strategies, by amount of available appropriations.

The amount given above allows calculation of the additional investment that is permitted when appropriations are applied as a buydown to a privately financed project: when one dollar of appropriations is used as a buydown, project investment increases by $\$ 0.77$. There is a limit, of course, since the total project investment here is limited to $\$ 100$ million.

As shown in Fig. 8, there is also a life-cycle-cost advantage to using appropriations to fund long-payback ECMs directly, as opposed to using the appropriations as up front payments in privately financed projects. The advantage is small for both large and small amounts of appropriations funding. Note that for Fig. 8, the investment quantities for the two options were forced to be equal. In this case, when the investment amount is increased by the amount of the available appropriations, and that amount is returned as an upfront payment at the end of the construction period, the result is a slight increase in the term of the financed project, causing higher interest costs and a higher life-cycle cost for the Financing with Buydowns strategy.

While using appropriations to directly fund long-payback ECMs may appear to have the lowest life-cycle cost for most values of appropriations funding, the option of applying appropriations as up-front payments to privately financed projects may be more advantageous for some agencies. For example, agencies may prefer to have a single point of contact in the ESCO rather than deal with multiple contracts and contractors. 


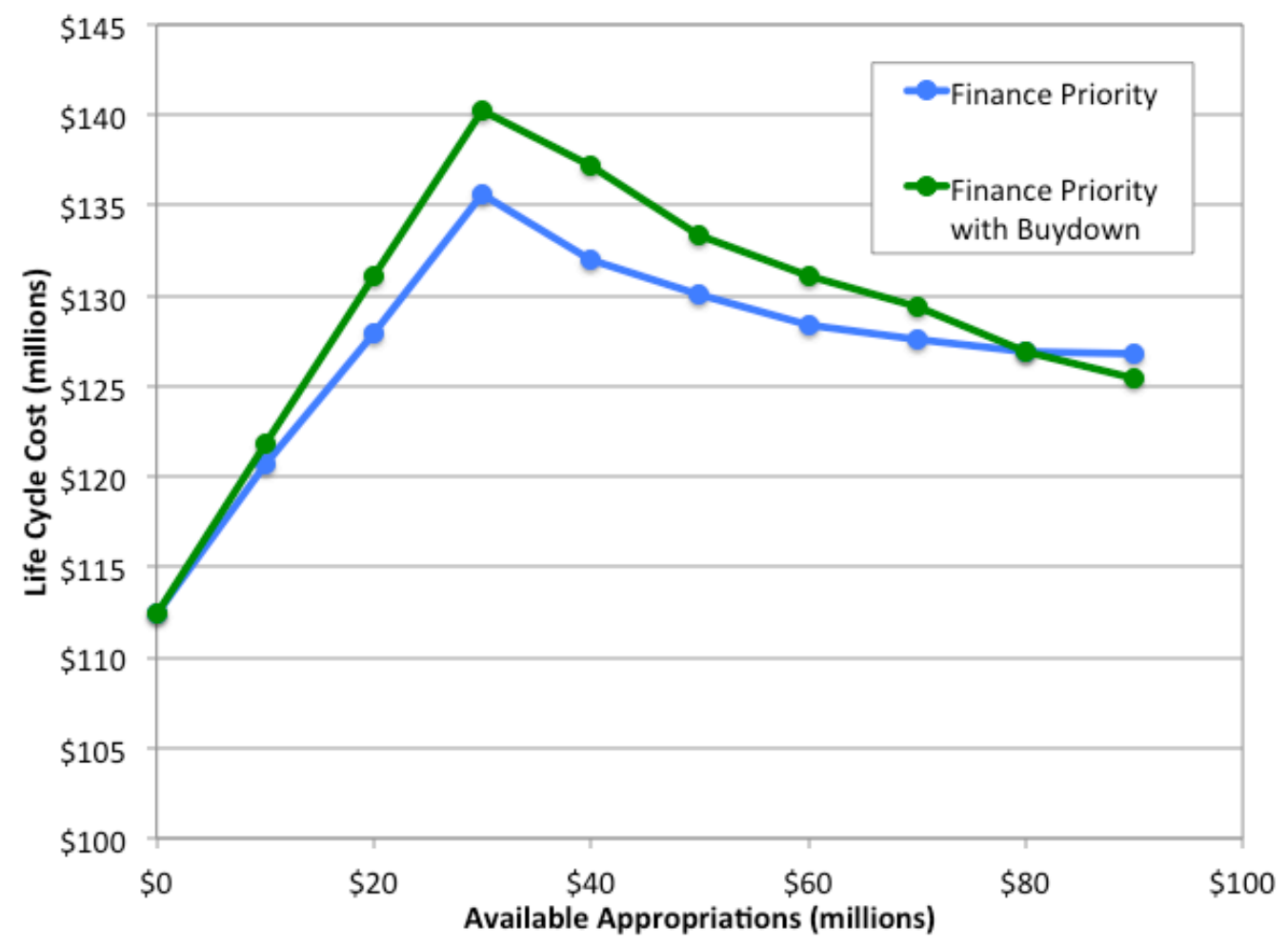

Fig. 8. Life-cycle cost of strategies 2 and 3, by amount of available appropriations.

In addition, there likely are other costs associated with implementing two projects vs. one that were not considered in this analysis. Costs of mobilization, interfacing with the installation, negotiating and acquiring approvals at the installation, hiring subcontractors, and others could all be significantly higher if measures have to be addressed on two separate occasions. Other factors - such as the cost of surveys and studies required to obtain funding from the agency (here assumed to be $5 \%$ ) and differences in the schedule of implementing the two projects - affect life-cycle cost as well (see, e.g., Hughes et al, Evaluation of Federal Energy Savings Performance Contracting - Methodology for Comparing Processes and Costs of ESPC and Appropriations-Funded Energy Projects. ORNL/TM-2002/150, March 2003).

\section{SENSITIVITY ANALYSIS}

The two main conclusions of this analysis are

1. If agencies expect to use a mix of appropriations and private financing to meet their energy management goals, then using appropriations to fund the efficiency measures with the shortest paybacks limits the ability to meet the goals.

2. Energy savings are maximized by using private financing to fund as many of the efficiency measures as possible.

These conclusions are based on three key parameters:

- Interest rate

- Discount rate

- Aggregate simple payback 
The values used for these parameters were chosen to be representative of current conditions in the economy and the state of energy efficiency in the US government as a whole. However, these conditions can change over time, and in the case of aggregate simple payback, may also vary from one agency to the next.

\subsection{INTEREST RATES}

To investigate the effect of higher interest rates, the premium was raised by 100 basis points to 208 basis points. That is, in the base case, a privately funded project with a performance period of 20 years would have a project interest rate of $4.08 \%$; whereas with the higher premium, such a project would have a project interest rate of $5.08 \%$. For the base case, each additional dollar of appropriations used to fund short-payback measures reduces total possible investment in energy efficiency by $\$ 2.83$. With the higher yield curve, each additional dollar of appropriations used to fund short-payback measures reduces total possible investment in energy efficiency by $\$ 2.82$. This is no improvement, however. Referring to Fig. 5 , where the starting point (i.e., the amount of investment possible with zero appropriations) in the base case is $\$ 77.9$ million, with the higher premium it is $\$ 69.2$ million.

For the base case, the analysis also calculated that in privately financed projects, every dollar applied as a buydown to the project increases total investment by $\$ 0.79$. With the higher yield curve, every dollar applied as a buydown to the project increases total investment by $\$ 0.87$. This result seems paradoxical at first, but is explained by the fact that when interest rates are very high, not much investment can be implemented without a buydown. So buydowns help more when interest rates are higher.

\subsection{DISCOUNT RATE}

The discount rate affects life-cycle-cost calculations only. A higher discount rate in effect reduces the cost of future payments relative to payments made in the present. For analyses made in 2011, the Office of Management and Budget recommended a discount rate of 3.9\%. Although this number is tied to interest rates, for the sensitivity analysis, only the discount rate was altered. With the discount rate at $3.9 \%$, the life-cycle costs of the three strategies move closer together. In Fig. 6 (which compares the life-cycle cost of using the three different strategies to implement the quantity of investment that is possible with the Appropriations Priority strategy), Appropriations Priority still has the highest life-cycle cost for appropriations amounts that permit the use of private financing, although the life-cycle cost premium over the other two strategies is reduced.

The same result is true of Fig. 8. With the higher discount rate, the life-cycle cost difference between the Finance Priority and the Finance Priority with Buydowns strategies is reduced, but the Finance Priority strategy still has a lower life-cycle cost. The two main conclusions noted earlier do not change.

\subsection{AGGREGATE SIMPLE PAYBACK}

A shorter aggregate simple payback means that the required measures deliver higher savings per dollar invested; conversely, with a longer aggregate simple payback, the measures deliver lower savings per dollar invested. Cases were run with aggregate simple paybacks of 15 and 19 years. While life-cycle costs changed somewhat, the relationships between the various strategies did not change, and the conclusions remain the same.

\section{SAVINGS-TO-INVESTMENT RATIO}

Some agencies have interpreted federal energy legislation to mean that each individual ECM installed at their facilities must have a savings-to-investment ratio (SIR) greater than one. The SIR of a given ECM 
depends on a number of factors, including its useful service life, energy prices, the inflation rate of energy and maintenance costs, and the discount rate. Although the analysis presented in this report did not calculate the SIR of individual measures, it did not exclude the long-payback ECMs present in the CTS database, such as renewable measures. It is expected that the SIR of many of these ECMs would be less than one. To assess whether limiting the SIR would change the report's conclusions, a truncated dataset was developed with an aggregate simple payback of 13 years and a maximum simple payback of 20 years. Given an inflation rate of $2 \%$ and a discount rate of $3.5 \%$, ECMs with simple payback of less than 20 years and service life of 20 years or greater would have SIRs greater than 1. The truncated ECM distribution is presented in Fig. 9.

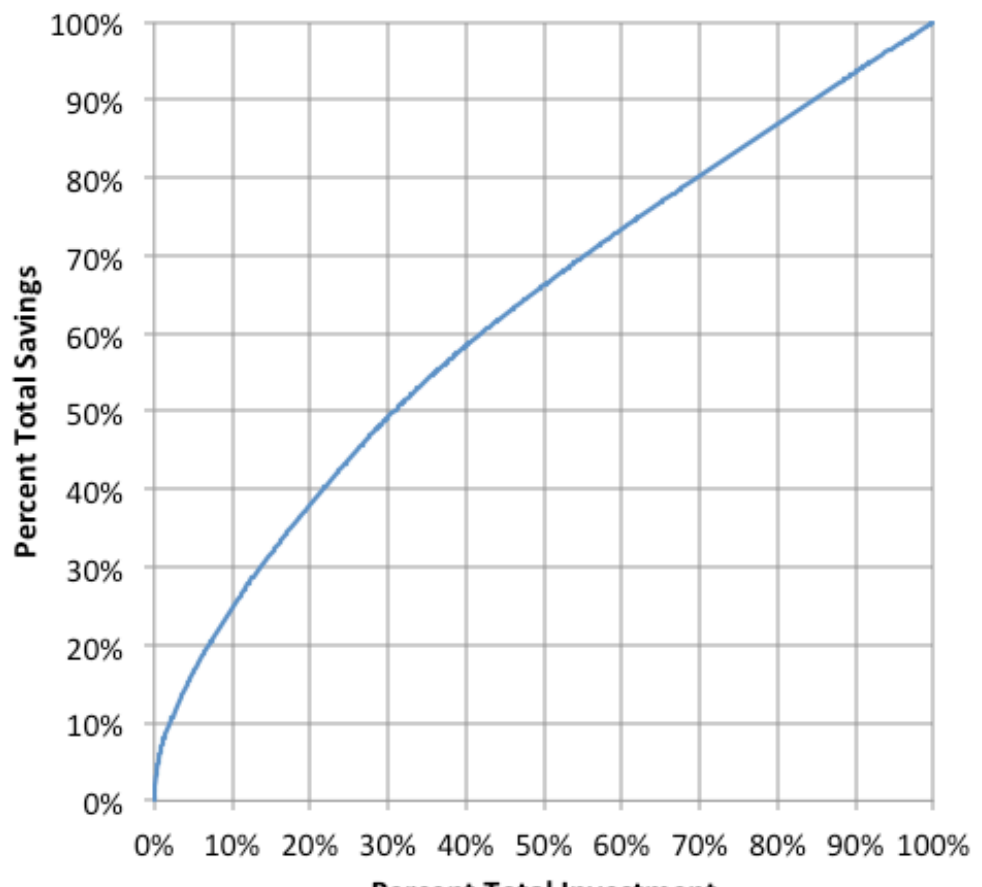

Percent Total Investment

Fig. 9. Percentage of total savings vs. percentage of total investment for a truncated dataset with an aggregate simple payback of 13 years and a maximum simple payback of 20.

Figure 10 presents the maximum investment for the Appropriations Priority strategy, given the truncated ECM distribution of Fig. 9. It is seen that using appropriations to directly fund the ECMs with the shortest paybacks has the same effect as with the full dataset: each additional dollar of appropriations used to fund short payback ECMs reduces total investment by about $\$ 2.87$. Likewise, as seen in Fig. 11, the Appropriations Priority strategy has a higher life-cycle cost than the other two strategies. Using appropriations to directly fund ECMs with the shortest paybacks makes the remaining measures more costly to implement using private financing. This effect is unchanged when the simple payback of ECMs is limited to 20 years. 


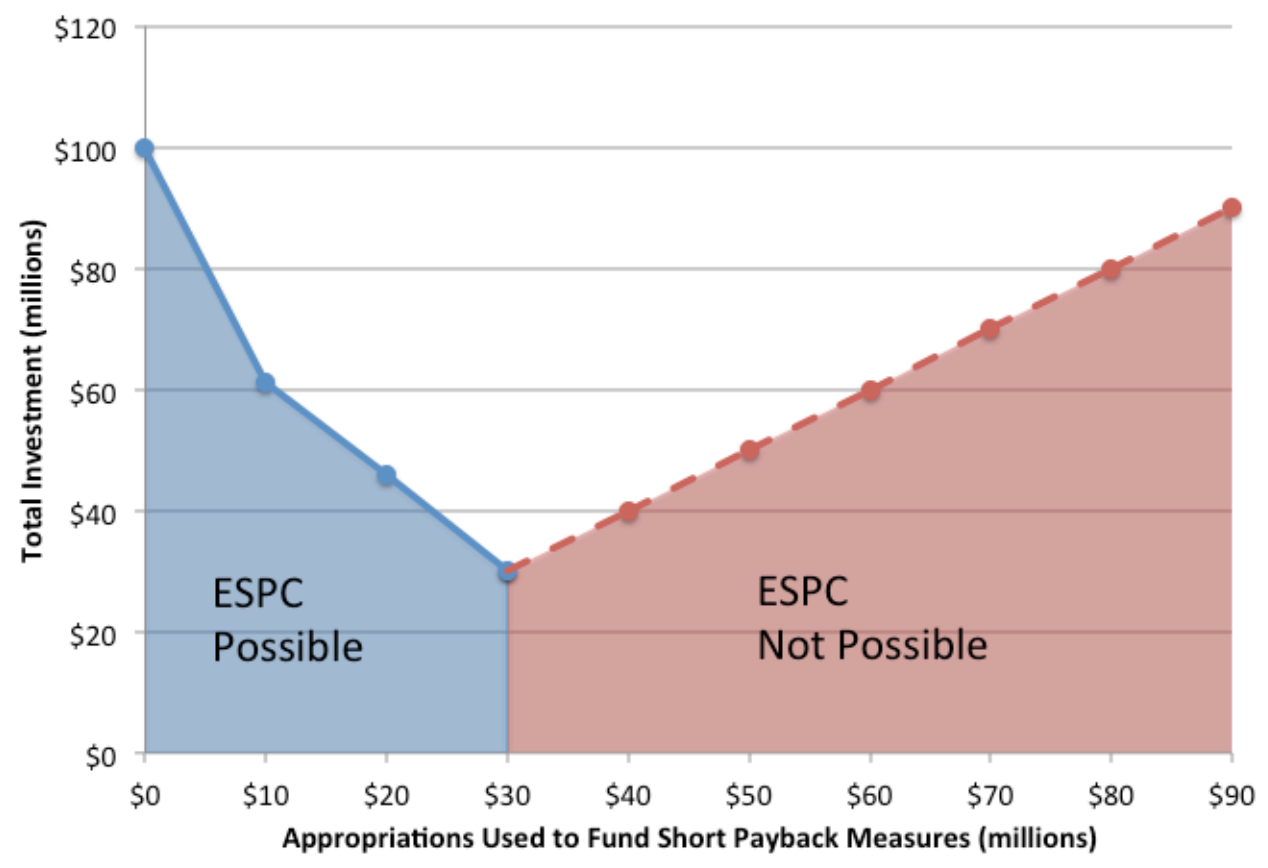

Fig. 10. Maximum possible investment for the Appropriations Priority strategy, for the truncated ECM distribution of Fig. 9. As with the full dataset (Fig. 5), using appropriations to directly fund ECMs with short paybacks limits total investment; if enough ECMs are installed using appropriations, a point is reached at which the savings of the remaining ECMs are insufficient to finance their installation in a pay-from-savings project with a term of less than the statutory maximum of 25 years.

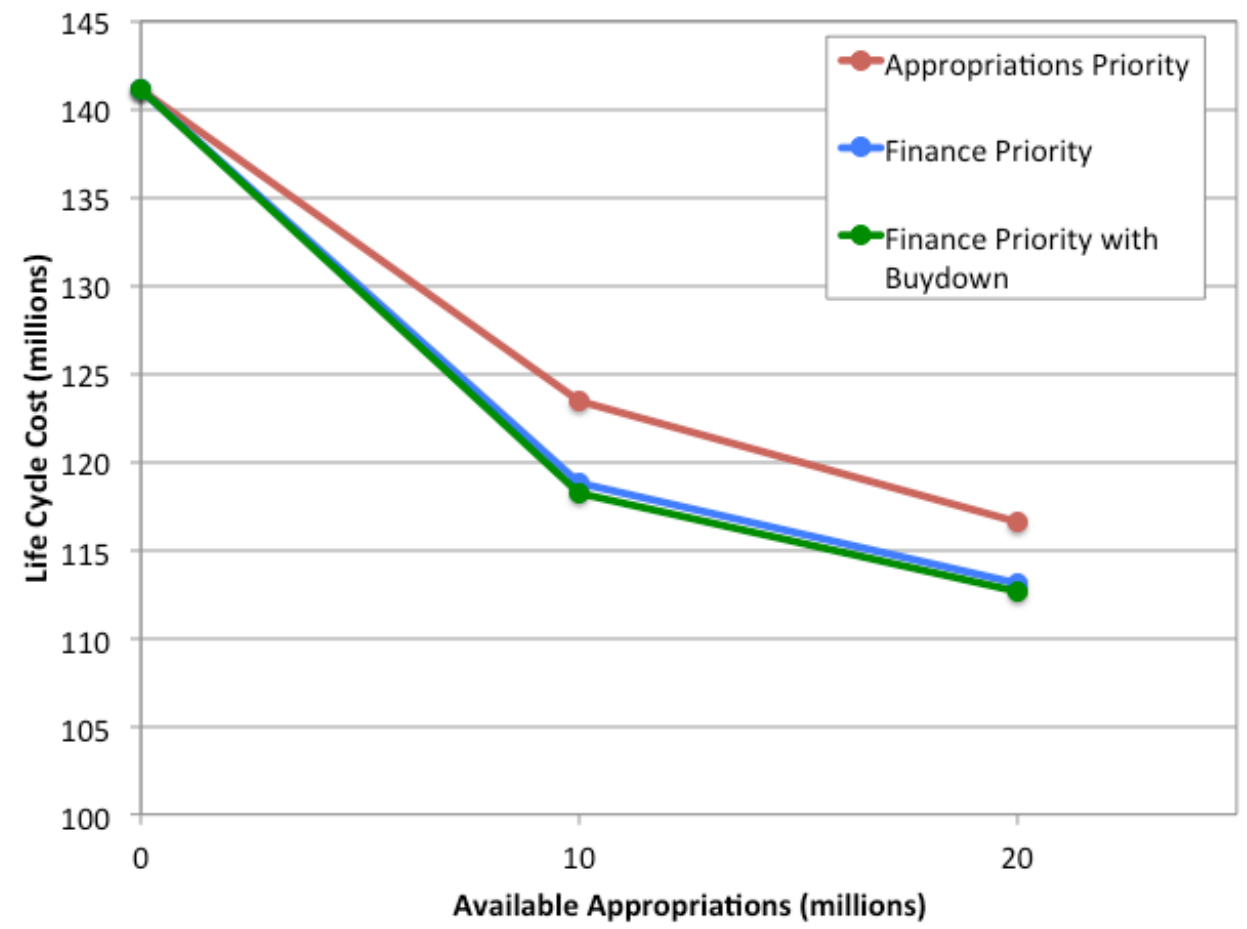

Fig. 11. Life-cycle cost of the three strategies for implementing the total amount of investment shown in Fig. 10 for each level of available appropriations, for the truncated ECM distribution shown in Fig. 9. It is seen that limiting the ECMs to a simple payback of less than 20 years does not change the fact that the Appropriations Priority strategy has the highest life-cycle cost. 


\section{CONCLUSIONS}

This report considers a representative set of ECMs based on a database that includes a wide spectrum of federal agencies. The objective was to analyze various strategies for combining appropriated funds with private financing. The analysis shows that in order to maximize savings and minimize overall life-cycle cost, the best strategy for the agency is to use private financing to fund as many of the ECMs as possible within the statutory maximum 25 -year project term, beginning with the shortest-payback ECMs. Available appropriations should either be applied to the privately financed project as a one-time payment from savings (i.e., as an "buydown") or used to directly fund longer-payback ECMs that cannot be included in the privately financed project.

These conclusions are unaffected by modest changes in interest rate, discount rate, and aggregate simple payback. Furthermore, the conclusions do not change when the ECM distribution is limited to simple paybacks of less than 20 years. Regardless of the ECM distribution, if energy conservation projects are to be installed using a mix of appropriations and private financing, then using the appropriations to fund the ECMs with the shortest paybacks limits total investment and raises life-cycle cost. Measures with short paybacks deliver larger savings per dollar invested, and measures with long paybacks deliver smaller savings per dollar invested. In financed projects, these streams of cost savings are used to pay the debt service on the borrowed capital (in addition to their use to fund M\&V and other performance period services). If an agency uses appropriations to directly fund short-payback measures, then the remaining measures generate less savings per dollar invested. The financed project is already at the statutory maximum contract term, so given a smaller savings stream, the only way to implement a financed project is to decrease the size of the loan. This decreases the amount of total investment. Life-cycle cost is increased because the financed project incurs additional interest costs. 
APPENDIX: SAMPLE COST CALCULATION 



\section{APPENDIX: SAMPLE COST CALCULATION}

The calculations for one instance of Strategy 2 are illustrated in detail below. The purpose is for the reader to be able to duplicate and check the calculations if so desired. The figures are provided in tabular form in Table 1.

In this example, the agency is assumed to require $\$ 100$ million in energy efficiency measures. The aggregate simple payback of these measures is assumed to be 17 years, so the first-year annual savings available from all of the measures is $\$ 5,882,353$.

Calculations show that with the assumptions above, and given the savings-investment curve of Fig. 5, a project in the amount of $\$ 77,869,310$ can be implemented using private financing with a project term equal to 23 years. Based on Fig. 5, 78\% of the investment delivers about $99 \%$ of the savings. The exact amount of the first-year savings is $\$ 5,795,622$.

To calculate the financed amount, first add $5 \%$ to the installed price of the efficiency measures, or $\$ 3,893,466$. The subtotal is $\$ 81,762,776$. The financing procurement price is assumed to equal two years of interest charges on the financed amount. This is found to be $\$ 7,507,642$. The financed amount is then $\$ 89,270,418$.

In addition to the privately financed project, the agency is assumed to have $\$ 10$ million in appropriations available. It uses this amount to fund the $10 \%$ of investment that immediately follows-in a list of available efficiency measures sorted by simple payback - the $78 \%$ of investment implemented using private financing. From Fig. 5, this quantity of investment delivers $1.06 \%$ of the savings, which corresponds to first-year savings of $\$ 62,327$.

The earliest cost the agency incurs is to pay a contractor to install the equipment for the directly funded project. It is assumed that the site where the project is installed has incurred an additional expense of 5\% of the amount of the appropriations in order to perform the surveys and studies necessary to justify receipt of the appropriations from the agency. Thus the expense to the agency is $\$ 10.5$ million, shown in year 1 of Column K of the balance sheet shown in Table 1.

A 2 year construction period is assumed for both the directly funded and the privately financed projects. Thus the guaranteed savings from the privately financed project begins in year 3 .

At the end of the construction period, the loan balance for the privately funded project is equal to the financed amount. The savings were calculated for year 1, and during the construction period the savings have increased by the rate of inflation, so they are equal to $(\$ 5,795,622)(1+.02)^{2}=\$ 6,029,766$. Assuming the agency accepts the project, a quantity of $\$ 1$ less than the first-year savings is available to pay the ESCO. This figure is shown in Column C.

With payments to the ESCO made at the beginning of the year, there is no interest cost in the first year of the performance period (during the construction period, the ESCO used the financing procurement price to pay interest to the financier). The ESCO's expenses during the first year are for O\&M on the installed equipment, and $\mathrm{M} \& \mathrm{~V}$ of savings. This is equal to $1.5 \%$ of the installed price of the efficiency measures, or $\$ 1,168,040$. The expense appears in Column F.

The agency makes a payment of $\$ 6,029,765$ to the ESCO. With expenses of $\$ 1,168,040$, the ESCO is able to make a principal payment of $\$ 4,861,725$ to the financier. The loan balance at the beginning of year 3 is then equal to the financed amount minus the principal payment, or $\$ 84,408,693$. 